\title{
Shukra dhatugata jwara rabies encephalitis
}

\begin{abstract}
Jwara (fever) is considered as most important among all diseases in Ayurveda as it afflicts the shareera (body), indriya (sense organs) and manas (mind). Shukra dhatugata jwara is characterized by 'Stabdha shepha' (rigidity of penis/erections/priapism), 'Shukra moksha' (excessive discharge of semen/spontaneous ejaculation) and 'Maranam prapnuyanti' (leads to death). Till date there is no clear understanding of Shukra dhatugata jwara and no works have been conducted on this topic. The present article aims to explore the condition of 'Shukra dhatugata jwara'. Shukra dhatugata jwara resembles with Rabies encephalitis (RE). RE is one of the oldest communicable diseases known to man. Transmission to humans is mainly through bites of infected rabid dogs, cats, bats, and other wild animals with case fatality rate approaching $100 \%$. The untreated disease presents as a progressive encephalomyelitis, which is invariably fatal. Rabies can present with a wide variety of clinical symptoms, ranging from hyper excitation and phobic spasms to coma and flaccid paralysis. The characteristic features of Shukra dhatugata jwara resembles with Rabies encephalitis with clinical presentation such as priapism/penile hyper excitability, spontaneous ejaculation, fever and ultimately leading to death. Reference of the condition like Rabies encephalitis is described in Ayurvedic texts under the domain of Shukra dhatugata jwara so many centuries earlier.
\end{abstract}

Keywords: rabies encephalitis, shukra dhatugata jwara, ayurveda, fever, priapism, spontaneous ejaculation
Volume 7 Issue 2 - 2017

Prasad Mamidi, Kshama Gupta

Department of Kayachikitsa, Parul University, India

Correspondence: Prasad Mamidi, Associate Professor, Department of Kayachikitsa, Faculty of Ayurveda, Parul University, Vadodara, Gujarat, India, Tel 75672222856, Email drprasadmamidi@gmail.com

Received: March 26, 2017| Published: May 30, 2017

\section{Introduction}

Jwara (fever) is considered as most important among all diseases in Ayurveda as it afflicts the shareera (body), indriya (sense organs) and manas (mind). ${ }^{1,2}$ It may be a symptom of some other condition or individual disease itself. Jwara is characterized by Santaapa (elevated body temperature), Aruchi (loss of appetite), Trishna (excessive thirst), Angamarda (body aches), Hridivyatha (pain/discomfort at epigastric/left hypochondriac region) and Janmaadau nidhane (commonly occurs at the time of birth and death of an individual). ${ }^{3}$ The main concept of Ayurvedic medicine is 'health exists when there is a balance between three 'doshas' (fundamental bodily elements) called Vata, Pitta and Kapha'. ${ }^{4}$ Doshas are the forces that create the physical body and determine various conditions like growth, ageing, health, disease and constitution of an individual. When doshas are in excess or depleted or misplaced they will produce various diseases. Doshas become vitiated in various manners. Vitiated doshas alone can't produce a disease in the absence of suitable ground i.e., abnormality or vitiation of srotas (channels). There are seven 'dhatus' (tissue elements/tissues) present in human body according to Ayurveda. They are Rosa (plasma), Rakta (blood), Mamsa (muscle), Medas (adipose tissue), Asthi (bone), Majja (marrow/nerve tissue) and Shukra (reproductive tissues). These are the structures which make up and support the body. The vitiated doshas spreads and get settled in the dhatus and produce a disease..$^{5-8}$

Based on the affected dhatu, Jwara is classified in to seven sub types, Rasa dhatugata jwara (fever residing/afflicting/involving rasa dhatu), Rakta dhatugata (fever involving blood), Mamsa dhatugata (fever involving muscles), Medo dhatugata (fever involving adipose tissue), Ashti dhatugata (fever involving bone), Majja dhatugata (fever afflicting bone marrow/nervous system) and Shukra dhatugata jwara (fever afflicting reproductive system). ${ }^{5-8}$ The present article is based on 'Shukra dhatugata jwara' as till date there is no clear understanding of it and no works were conducted on this topic. The present article aims at better understanding/to explore the similarities between the conditions of 'Shukra dhatugata jwara' and 'Rabies encephalitis'.

\section{Shukra dhatugata jwara}

According to 'Sushruta samhita', 'Shukra dhatugata jwara' is characterized by 'Stabdha shepha' (rigidity of penis/erections/priapism), 'Shukra moksha' (excessive discharge of semen/spontaneous ejaculation) and 'Maranam prapnuyanti' (leads to death). As fire extinguished after consumption of fuel and poison subsides after destroying tissues, Shukra dhatugata jwara subsides after killing the patient.? In 'Charaka samhita' also similar views are expressed. Shukra dhatugata jwara is characterized by 'Shukra moksha' (excessive ejaculation/spontaneous ejaculation) and 'Praana vinaasha' (leads to death) according to 'Charaka samhita. ${ }^{8}$ There is no specific etiology and treatment explained for Shukra dhatugata jwara. It is unanimous that, Shukra dhatugata jwara is characterized by penile rigidity/ erections/priapism, excessive/spontaneous ejaculation with fever and $100 \%$ fatality.

\section{Rabies encephalitis (RE)}

Rabies has been known to mankind since antiquity. Rabies was already known in India many centuries earlier, and graphic descriptions of hydrophobia as well as of animal rabies are found in ancient $\mathrm{Ve}$ dic medical texts. ${ }^{9}$ The term rabies is derived from the old Indian root word 'rabh', which means 'to make violent'. RE is an acute central nervous system infection caused by a type of RNA virus. RE is one of the oldest communicable diseases known to man. Transmission to humans is mainly through bites of infected rabid dogs, cats, bats, and other wild animals. The unique mode of transmission, virtually exclusive neurotransmission shown by the agent and the complete hopelessness of the established disease set rabies apart from other zoonotic diseases transmitted to man. ${ }^{10}$ Non bite exposure can also occur as a result of contamination of open wounds or mucous membranes, aerosol transmission, and corneal and organ transplantation. ${ }^{11}$

Rabies is one of the most deadly infectious diseases, with a case fatality rate approaching $100 \%$. The untreated disease presents as a progressive encephalomyelitis, which is invariably fatal. It is difficult to diagnose rabies virus infection ante-mortem. No clinical signs of the disease are pathognomonic for rabies. ${ }^{12}$ Incubation period of 
rabies is typically 2 to 8 weeks. Human rabies may present in one of two forms; encephalitic and paralytic. Encephalitic rabies is characterized by the initial symptoms which are non-specific, such as fever, malaise, anorexia, cough, and pain or parasthesia at the bite site. Subsequently patients develop hydrophobia, aerophobia, hyper salivation, hyper irritability, hyperactivity and priapism. Neurological symptoms such as seizures, agitation, and alternating mood swings often occur. Most of the patients die within ten days of the onset of neurological symptoms. ${ }^{10}$ Paralytic form consists of ascending paralysis and later cerebral involvement. ${ }^{13}$ Atypical presentation of rabies poses significant problems in the diagnosis, especially when the patient is comatose and in the absence of pathognomonic signs. Death is usually due to respiratory failure. Rabies can present with a wide variety of clinical symptoms, ranging from hyper excitation and phobic spas$\mathrm{ms}$ to coma and flaccid paralysis. Hydrophobia alone should not be taken as pathognomonic feature to diagnose rabies. ${ }^{14}$ Despite aggressive approaches to therapy human rabies remains an almost invariably fatal disease and no effective therapy is available for human rabies. ${ }^{15}$

\section{Shukra dhatugata jwara and rabies encephalitis}

There is some similarity found between the two conditions, Shukra dhatugata jwara and RE. Shukra dhatugata jwara is characterized by fever, erections (abnormal / painful / rigidity of penis), excessive ejaculation / spontaneous ejaculation and highly fatal.

Jwara (Fever): Fever is one of the initial symptoms of RE and it may be associated during the later phases of the disease (encephalitis) also.

Stabdha shepha (rigidity of penis/abnormal erections/priapism): Priapism is defined as complete or partial penile tumescence that persists for greater than 4hours beyond sexual stimulation, or is not associated with sexual stimulation. It may be ischemic, non-ischemic or stuttering. ${ }^{16}$ Priapism is a pathological condition representing a true disorder of penile erection that persists for more than 4hour and is beyond, or is unrelated to, sexual interest or stimulation. Ischemic priapism is the most common form of priapism, and it is usually painful, with a rigid erection characterized by absent or reduced intra cavernous arterial inflow. Rabies is one of the potential causative factors for ischemic priapism. ${ }^{17} \mathrm{~A}$ case report has described the extremely rare occurrence of penile hyper excitability as the initial clinical manifestation of human rabies. A wide variety of urogenital symptoms were rarely reported in rabies. Penile pain has been reported as the earliest symptoms of rabies. Priapism is also another rare but well documented manifestation of rabies. The exact cause of the urogenital symptoms that may rarely accompany rabies is not clear. ${ }^{18}$ Stabdha medhrata / Stabdha sheapha denotes priapism or penile hyper excitability.

Shukra moksha (excessive/spontaneous ejaculation): Recurrent ejaculation along with penile hyper excitability has preceded the more classical manifestations such as hydrophobia and aerophobia by approximately 8hours in a rabies patient. Recurrent ejaculation and penile hyper excitability is a unique and unusual presentation of human rabies. Priapism and recurrent ejaculation has been postulated to be secondary to damage to the amygdaloid nucleus in the temporal pole. Recurrent ejaculation may be the earliest manfifestation of rabies in endemic areas with a history of contact with dogs. Rabies should be suspected/ascertained in a patient presenting with urogenital symptoms such as penile pain, penile hyper excitability/priapism and recurrent ejaculation with obscure etiology. ${ }^{18}$ The canine rabies virus infects motor end plates in muscles after deep bites; after some period of low-rate replication of virus in infected muscles, enters the nerves supplying that muscle. The virus enters the central nervous system days before the development of clinical symptoms. Involvement of the hippocampus, hypothalamus and the limbic system can explain the typically dramatic clinical features. Centrifugal spread from central nervous system to skin, muscle spindles, immune organs and viscera via sensory nerves occurs later which may be the cause for dysautonomia (autonomic dysfunction) seen in rabies. ${ }^{9}$ This explanation is similar to the Ayurvedic description of spread of doshas from one dhatu to another dhatu ultimately reaching shukra dhatu (which is pervasive all over the body) and destroying it.

Maranam prapnuyanti/Praana vinaasha (Fatal/leads to death): Shukra dhatugata jwara is untreatable condition and it leads to death according to Ayurveda. No treatment is explained in Ayurvedic texts for Shukra dhatugata jwara. Rabies is an acute progressive encephalomyelitis. The patients with rabies become comatose after 1-2weeks of acute neurological phase and die of arrhythmia or myocarditis. ${ }^{19}$ Rabies patients usually succumb to failure of basic central vegetative functions, although death may also be due to concomitant rabies myocarditis. ${ }^{10}$

\section{Conclusion}

Shukra dhatugata jwara resembles with Rabies encephalitis. The characteristic features of Shukra dhatugata jwara like, stabdha shepha (penile rigidity), shukra moksha (excessive ejaculation) and marana (death) along with jwara (fever) resembles with priapism/penile hyper excitability, spontaneous ejaculation, fever and ultimately leading to death etc features of Rabies encephalitis. There is no treatment for both the conditions. Reference of the condition like Rabies encephalitis is described in Ayurvedic texts under the domain of Shukra dhatugata jwara so many centuries earlier.

\section{Acknowledgments}

None.

\section{Conflicts of interest}

Author declares there are no conflicts of interest.

\section{Funding}

None.

\section{References}

1. Seethadevi P, Sharma VS. Understanding of taruna jwara chikitsa sootra. World Journal of Pharmacy and Pharmaceutical sciences. 2016;5(7):576-583.

2. Talawar PD . Avasthanurupa chikitsa in jwara and its role in clinical practice. Unique Journal of Ayurvedic and Herbal Medicines. 2015;3(4):109-111.

3. Nagaraj S, Nidhin V. A study on vishama jwara nidaana with special reference to risk factors in malarial fever. IAMJ. 2015;3(8):2318-2325.

4. Nishant K, Poonam BS, Yasmeen P et al. Concept of gatavata from Ayurvedic perspective-A review article. IAMJ. 2015;3(3):862-868.

5. Panja AK, Chattopadhyaya A, Chaudhuri S. A comprehensive outlook of sannipata. Ayu. 2011;32(2):154-164.

6. Chakrapani. Agnivesha, Charaka samhita Elaborated by Charaka and Dridhabala commentary. In: Trikamji Acharya VJ (Ed.), Sutra sthana, Deergham jeevitiyam adhyaya. Varanasi, India: Chaukhamba surbharati prakashan; 2008. p. 16.

7. Dalhana. Sushruta, Sushruta samhita Commentary. In: Trikamji Acharya VJ \& Acharya NR (Eds.), Uttara tantra, Jwara pratishedha adhyaya 39/83-89. Chaukhamba orientalia, Varanasi, India. 2009;pp.678. 
8. Chakrapani. Agnivesha, Charaka samhita Elaborated by Charaka and Dridhabala commentary. In: Trikamji Acharya VJ (Ed.), Chikitsa sthana, Jwara chikitsitiyam adhyaya 3/82. Varanasi, India: Chaukhamba surbharati prakashan; 2008. p. 406.

9. De Souza A, Madhusudana SN. Survival from rabies encephalitis. $J$ Neurol Sci. 2014;339(1-2):8-14.

10. Awasthi M, Parmar H, Patankar T, et al. Imaging findings in Rabies Encephalitis. AJNR Am J Neuroradiol. 2001;22(4):677-680.

11. Co SJ, Mackenzie IR, Shewchuk JR. Rabies encephalitis. Radiographics. 2015;35(1):235-238.

12. Fooks AR, Banyard AC, Horton DL, et al. Current status of rabies and prospects for elimination. Lancet. 2014;384(9951):1389-1399.

13. Tunkel AR, Glaser CA, Bloch KC, et al. The management of encephalitis: clinical practice guidelines by the infectious diseases society of America. 2008;47(3):303-327.
14. Mohite AP, Prasad V, Rajam L, et al. Rabies encephalitis. Indian pediatrics. 2007;44(9):702-704.

15. Jackson AC. Rabies pathogenesis update. Rev Pan-Amaz Saude. 2010;1(1):167-172.

16. Tay YK, Spernat D, Rzetelski-West K, et al. Acute management of priapism in men. B J U international. 2012;3:15-21.

17. Salonia A, Eardley I, Giuliano F, et al. Guidelines on priapism. European Association of Urology. 2015;1-23.

18. Udwadia ZF, Udwadia FE, Rao PP, et al. Penile hyper excitability with recurrent ejaculations as the presenting manifestation of a case of rabies. Post graduate medical journal. 1988;64:85-86.

19. Wu HH, You KH, Lo HY. Diagnosis, Management, and Prevention of Rabies. Epidemiology Bulletin. 2013;29(S):23-32. 